\title{
PENGARUH PERUBAHAN TEMPERATUR ATMOSFER TERHADAP JARAK TERBANG MAKSIMUM PESAWAT N219 PADA FASE TERBANG JELAJAH
}

\author{
Gita Kusumastuti ${ }^{1}$, Hary Sutjahjono ${ }^{2}$, Dedi Dwilaksana ${ }^{2}$ \\ ${ }^{1}$ Mahasiswa Jurusan Teknik Mesin, Universitas Jember \\ ${ }^{2}$ Staf Pengajar Jurusan Teknik Mesin, Universitas Jember \\ E-mail : gitakusumastuti16@gmail.com
}

Naskah diterima: 03 Desember 2017 ; Naskah disetujui: 28 Desember 2017

\begin{abstract}
ABSTRAK
Pesawat N219 sebagai pesawat yang masih dalam masa uji terbang perlu dilakukan evaluasi dan penyempurnaan di berbagai bidang, salah satunya adalah bidang performance. Bidang ini mengkaji prestasi terbang seperti range maksimum yang dapat ditempuh pesawat dengan menggunakan kapasitas bahan bakar yang tersedia. Untuk mengetahui pengaruh kondisi atmosfer terhadap prestasi terbang maka pada penelitian ini diberikan variasi temperatur atmosfer yaitu pada kondisi ISA 0, ISA+10, ISA+20, dan ISA+30. Fase terbang jelajah (cruise) merupakan fokus kajian dalam penelitian ini karena fase tersebut adalah fase dominan baik dalam hal jarak, waktu, maupun konsumsi bahan bakar. Metode yang digunakan adalah metode specific fuel consumption. Metode ini digunakan untuk menentukan kecepatan yang dapat menghasilkan range maksimum. Tujuan dari penelitian ini untuk mengetahui pengaruh dari perubahan temperatur atmosfer terhadap range maksimum pesawat N219 pada fase terbang jelajah. Hasil perhitungan menunjukkan bahwa semakin besar peningkatan temperatur terhadap kondisi ISA 0 maka range maksimum yang dapat dicapai oleh pesawat juga semakin meningkat. Pada kondisi ISA 0 range maksimum yaitu $1946,48 \mathrm{~km}$ dan terus mengalami peningkatan hingga ISA+30 yaitu sebesar 2 224,36 km. Hal ini terjadi karena dengan meningkatnya temperatur maka massa jenis udara semakin menurun, menyebabkan specific air range meningkat, sehingga range maksimum pesawat juga meningkat.
\end{abstract}

Kata Kunci: Pesawat N219, terbang jelajah, specific air range.

\section{PENDAHULUAN}

Pesawat N219 adalah pesawat multifungsi berkapasitas 19 penumpang dan 2 kru presawat. Pesawat ini dirancang agar mudah dikonfigurasi ulang sehingga dapat berubah fungsi sesuai kebutuhan, seperti pesawat penumpang, pesawat kargo, pesawat patroli atau pengawas, serta pesawat evakuasi medis. Sebelum dapat diproduksi massal, pesawat N219 sebagai pesawat yang masih dalam masa uji terbang perlu dilakukan evaluasi dan penyempurnaan di berbagai bidang seperti bidang performance. Performance adalah bagian dari mekanika terbang yang menghitung gerak translasi dengan menggunakan hukum gerak Newton [1].

Dalam penerbangan, pesawat mengalami berbagai fase terbang. Fase terbang jelajah (cruise) adalah fase dominan yang memerlukan jarak paling jauh, membutuhkan bahan bakar paling banyak, dan waktu tempuh paling lama [2]. Oleh karena itu, fase terbang jelajah menjadi fokus kajian pada penelitian ini. Pada fase ini pesawat cenderung berada pada kecepatan dan ketinggian yang relatif konstan [1]. Fase terbang jelajah dimulai setelah berakhirnya fase climb dan berakhir saat pesawat mulai mengalami pengurangan ketinggian. Selama fase ini pesawat berada pada kondisi gerak steady [4]. Persamaan gerak yang digunakan yaitu pesawat dalam keadaan equilibrium (setimbang) antara thrust (T) dengan drag (D) dan antara lift (L) dan berat pesawat (W) [3].

Pesawat yang terbang di berbagai wilayah akan dipengaruhi kondisi atmosfer yang berbeda-beda. Unsur utama yang mempengaruhi kondisi atmosfer adalah suhu dan tekanan udara yang pada tahap selanjutnya juga akan mempengaruhi prestasi terbang pesawat [5]. Prestasi terbang pesawat berbeda-beda tergantung fungsi dari pesawat tersebut. Dalam hal ini pesawat N219 digunakan sebagai pesawat transportasi komersil sehingga perlu diketahui jarak tempuh maksimum pesawat. Berdasarkan hal tersebut maka perlu dilakukan penelitian mengenai prestasi terbang yaitu jarak terbang maksimum pesawat pada fase terbang jelajah (cruise) dengan pengaruh kondisi atmosfer yang berbeda-beda.

Tujuan dari penelitian ini adalah untuk mengetahui pengaruh perubahan temperatur atmosfer terhadap jarak jelajah maksimum pesawat sehingga dapat diketahui prestasi terbang pesawat N219 pada fase terbang jelajah. 


\section{METODOLOGI}

Penelitian ini dilakukan dalam beberapa tahapan yaitu observasi dan pengambilan data yang dilakukan di Divisi Aerodinamik, PT. Dirgantara Indonesia, serta pengolaha dan analisa data yang dilakukan di Laboratorium Rekayasa Mekanik, Fakultas Teknik, Universitas Jember. Penelitian ini dilakukan dalam rentang waktu bulan Agustus - Oktober 2017. Peralatan yang digunakan untuk mendukung terlaksananya penelitian ini adalah sebagai berikut :

- Pesawat N219

- Terowongan angin (wind tunnel)

- Sistem propulsi pesawat

- Software Microsoft Excel 2016

Prosedur Penelitian

a) Mempelajari literatur yang berhubungan dengan penelitian;

b) Melakukan pengamatan untuk mengetahui cara pengumpulan data prestasi terbang pesawat N219;

c) Melakukan pengumpulan data yang diperlukan untuk menentukan prestasi terbang pesawat dari penerbangan perdana pesawat N219;

d) Melakukan perhitungan massa jenis udara;

e) Menentukan koefisien lift $\left(C_{L}\right)$ dan koefisien drag $\left(C_{D}\right)$;

f) Menentukan gaya hambat (D) yang dialami pesawat;

g) Menentukan power required;

h) Menentukan specific fuel consumption;

i) Menghitung specific air range;

j) Menentukan kecepatan pada kondisi maksimum melalui grafik specific air range;

k) Menentukan fuel flow pada kecepatan yang telah ditentukan;

1) Menghitung waktu tempuh pesawat pada fase terbang jelajah;

m) Menghtiung jarak terbang jelajah maksimum pesawat pada fase terbang jelajah;

n) Melakukan analisa dari hasil perhitungan data;

o) Mengambil kesimpulan berdasarkan analisa yang telah dilakukan.

\section{HASIL DAN PEMBAHASAN}

\section{Karakteristik Kondisi Penerbangan}

Terdapat berbagai aspek yang mempengaruhi kondisi penerbangan pesawat antara lain adalah kondisi atmosfer. Hasil perhitungan karakteristik kondisi terbang pesawat pada ketinggian $10000 \mathrm{ft}$ atau $3048 \mathrm{~m}$, dengan berat pesawat pada kondisi maksimum take-off weight yaitu $7031 \mathrm{~kg}$, dan variasi kondisi atmosfer ISA 0 , ISA +10 , ISA +20 , ISA +30 ditunjukkan pada Tabel 1. Dari Tabel 1 dapat diketahui bahwa kondisi atmosfer mempengaruhi massa jenis udara. Semakin meningkatnya kondisi atmosfer terhadap kondisi ISA 0 menyebabkan massa jenis udara semakin berkurang. Namun massa jenis udara tidak mengalami perubahan yang terlalu signifikan terhadap perubahan kondisi atmosfer.

Tabel 1. Data Karakteristik Kondisi Penerbangan

\begin{tabular}{ccccc}
\hline ISA & $\mathbf{0}$ & $+\mathbf{l 0}$ & $\mathbf{+ 2 0}$ & $+\mathbf{3 0}$ \\
\hline $\mathbf{h}(\mathbf{m})$ & 3048 & 3048 & 3048 & 3048 \\
$\mathbf{p}\left(\mathbf{N} / \mathbf{m}^{2}\right)$ & 69681,38 & 69681,38 & 69681,38 & 69681,38 \\
$\mathbf{T}(\mathbf{K})$ & 268,338 & 268,338 & 268,338 & 268,338 \\
$\mathbf{p}\left(\mathbf{k g} / \mathbf{m}^{\mathbf{3}}\right)$ & 0,90464 & 0,87214 & 0,84189 & 0,81367 \\
$\mathbf{g}\left(\mathbf{m} / \mathbf{s}^{2}\right)$ & 9,79729 & 9,79729 & 9,79729 & 9,79729 \\
$\mathbf{W}\left(\mathbf{k g} \cdot \mathbf{m} / \mathbf{s}^{2}\right)$ & 68884,72 & 68884,72 & 68884,72 & 68884,72 \\
\hline
\end{tabular}

Selain data pada Tabel 1, terdapat aspek lain yang juga mempengaruhi kondisi penerbangan pesawat yaitu specific fuel consumption. Specific fuel consumption tersebut diperoleh dari penerbangan perdana (flight test) pesawat N219. Dari penerbangan perdana tersebut diperoleh data performance sehingga dapat dihasilkan grafik antara kecepatan dengan specific fuel consumption yang ditampilkan pada Gambar 1. Dari Gambar 1 dapat diketahui bahwa semakin meningkatnya kecepatan terbang menyebabkan specific fuel consumption semkain menurun, dan semakin meningkatnya tempertaur atmosfer terhadap kondisi ISA 0 menyebabkan specific fuel consumption semakin meningkat.

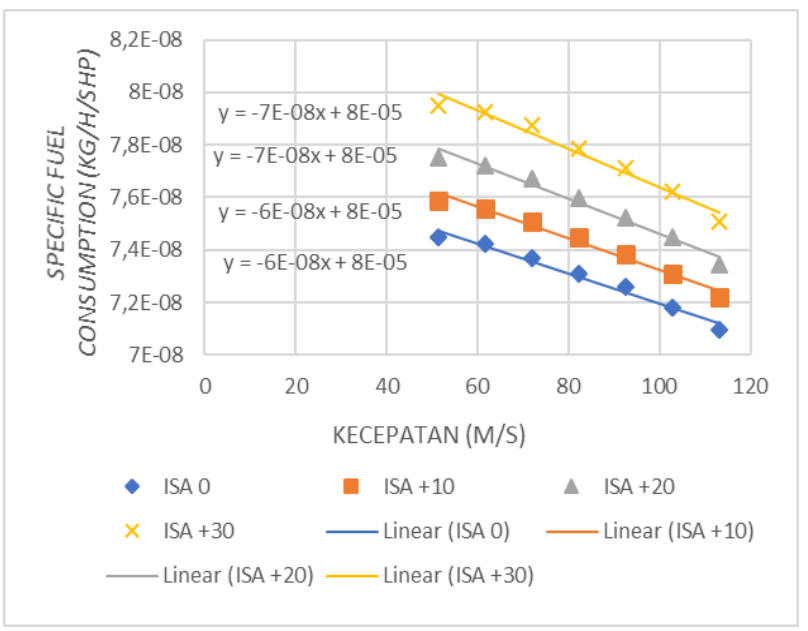

Gambar 1. Specific Fuel Consumption

\section{Specific Air Range}

Metode perhitungan dengan menggunakan specific air range menghasilkan grafik antara kecepatan dengan specific air range (SAR) dan grafik tersebut digunakan untuk menentukan kecepatan terbang pesawat yang dapat menghasilkan range atau jarak tempuh maksimum. Range maksimum pada fase terbang jelajah diperoleh dari titik maksimum grafik SAR tersebut [6]. Dari perhitungan yang dilakukan dengan mengkombinasikan data 
karakteristik pesawat dan kondisi atmosfer maka dapat dihasilkan grafik pada Gambar 2. Grafik pada Gambar 2 tersebut menunjukkan bahwa peningkatan temperatur atmosfer terhadap kondisi ISA 0 menyebabkan nilai specific air range maksimum mengalami penurunan. Namun penurunan tersebut tidak menyebabkan nilai sprecific air range maksimum pada ISA 0 , ISA +10 , ISA+20, dan ISA+30 mengalami perbedaan yang signifikan.

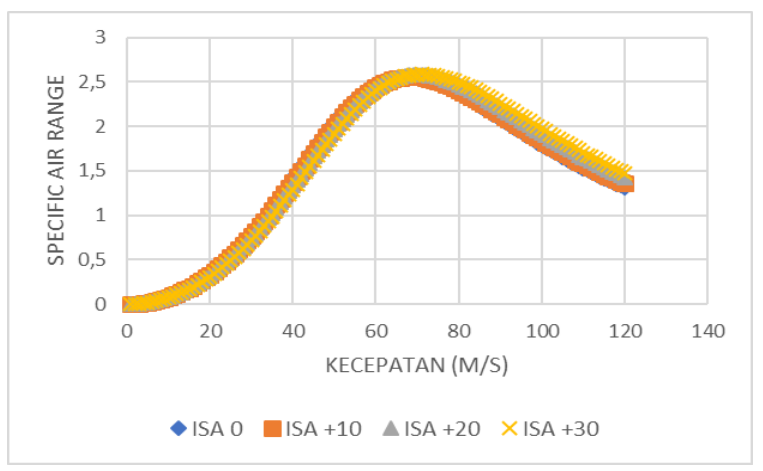

Gambar 2. Specific Air Range

Kecepatan terbang untuk range maksimum pesawat dapat diperoleh dengan cara menentukan nilai maksimum specific air range dari grafik di masingmasing kondisi atmosfer. Cara yang digunakan untuk menentukan nilai maksimum pada masing-masing grafik adalah dengan mem-plot 5 data sebelum puncak grafik dan 5 data setelah puncak grafik yang ditampilkan dalam Gambar 3. Dari data tersebut maka dapat diperoleh persamaan kemudian dilakukan penurunan dari persamaan tersebut sehingga diperoleh nilai kecepetan untuk range maksimum. Dari Gambar 3 dapat diketahui bahwa semakin meningkatnya temperatur atmosfer terhadap kondisi ISA 0 menyebabkan semakin meningkatnya kecepatan untuk memperoleh range maksimum.

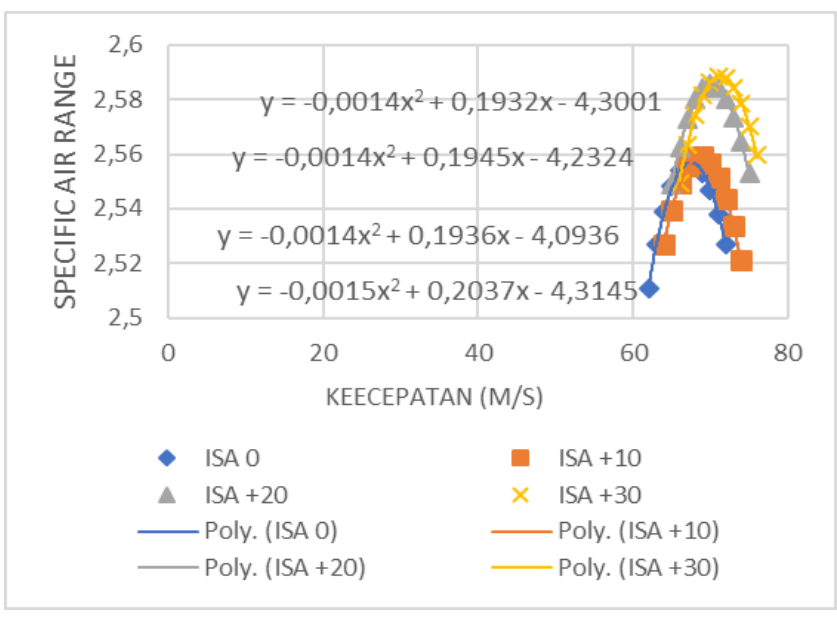

Gambar 3. Kecepatan pada Range Maksimum

\section{Fuel Flow}

Fuel flow pesawat adalah salah satu faktor penting yang harus diketahui berkaitan dengan prestasi terbang pesawat. Hal ini dapat mempengaruhi biaya operasional penerbangan, dampak emisi terhadap lingkungan, dan faktor efektivitas penerbangan pesawat [7]. Fuel flow atau aliran bahan bakar diperoleh dari data sistem propulsi pesawat $\mathrm{N} 219$ setelah pelaksanaan terbang perdana (flight test). Terdapat berbagai aspek yang mempengaruhi fuel flow antara lain ketinggian terbang, kecepatan pesawat, dan kondisi atmosfer. Grafik antara kecepatan dengan fuel flow tertera pada Gambar 4. Berdasarkan grafik pada Gambar 4 dapat diketahui bahwa semakin meningkatnya kecepatan terbang pesawat menyebabkan fuel flow semkain meningkat, dan semakin meningkatnya temperatur atmosfer terhadap kondisi ISA 0 menyebabkan fuel flow semakin berkurang.

Data-data fuel flow yang diperoleh selanjutnya dapat digunakan untuk menentukan waktu tempuh pesawat dengan cara memunculkan trendline dan persamaan dari masing-masing kondisi. Persamaan tersebut digunakan untuk menentukan fuel flow pada kecepatan maksimum yang telah diperoleh dari kondisi specific air range maksimum. Hasil perhitungan fuel flow untuk kecepatan yang telah ditentukan kemudian digunakan sebagai faktor pembagi dari berat bahan bakar pesawat N219 sehingga waktu tempuh pesawat pada fase terbang jelajah dapat diketahui.

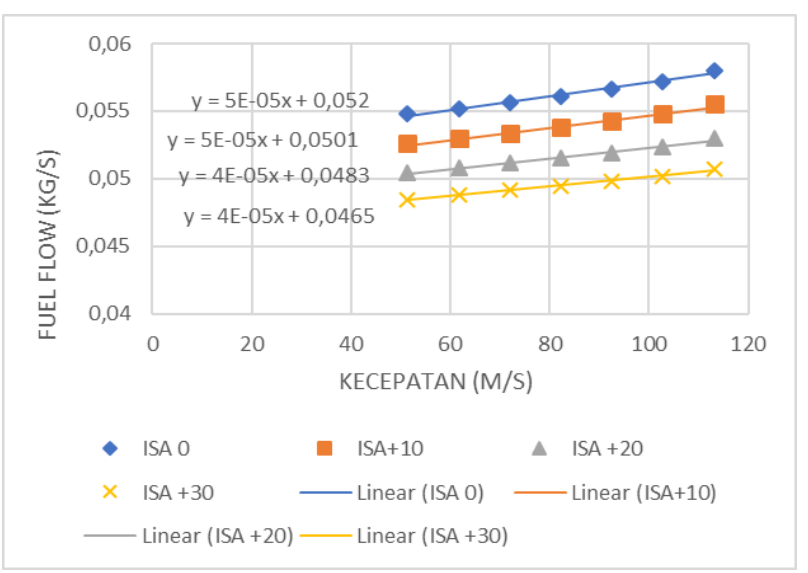

Gambar 4. Fuel Flow

\section{Range Maksimum}

Perhitungan range maksimum dilakukan dalam beberapa tahapan antara lain menentukan kecepatan terbang yang digunakan, fuel flow pada kecepatan yang telah ditentukan, waktu tempuh pesawat, dan pada akhirnya akan diperoleh nilai range maksimum. Berdasarkan perhitungan parameter-parameter tersebut maka diperoleh hasil seperti ditunjukkan pada Tabel 2 berikut. 
Tabel 2. Hasil Perhitungan Kriteria Terbang Pesawat

\begin{tabular}{c|cccc} 
ISA & $\begin{array}{c}\text { VMAKs } \\
(\text { KTAS) }\end{array}$ & $\begin{array}{c}\text { Fuel Flow } \\
(\mathbf{k g} / \mathbf{s})\end{array}$ & $\begin{array}{c}\text { Waktu } \\
(\mathbf{s})\end{array}$ & $\begin{array}{c}\text { Range } \\
(\mathbf{k m})\end{array}$ \\
\hline $\mathbf{0}$ & 132,101 & 0,055 & 28666,85 & 1946,479 \\
$\mathbf{+ 1 0}$ & 134,519 & 0,054 & 29650,57 & 2050,125 \\
$\mathbf{+ 2 0}$ & 135,145 & 0,051 & 31089,36 & 2159,600 \\
$\mathbf{+ 3 0}$ & 134,241 & 0,049 & 32237,11 & 2224,360
\end{tabular}

Berdasarkan hasil perhitungan tersebut maka dapat ditampilkan grafik seperti pada Gambar 3. Dari Gambar 3 dapat terlihat jelas bahwa range maksimum pesawat berbanding lurus dengan peningkatan temperatur atmosfer. Semakin tinggi peningkatan temperatur terhadap kondisi ISA 0 menyebabkan semakin meningkatnya nilai range maksimum pesawat. Range maksimum pesawat pada ketinggian $10000 \mathrm{ft}$ memiliki nilai terendah pada kondisi ISA 0 dan memiliki nilai tertinggi pada kondisi ISA +30 . Range maksimum pesawat pada ISA 0 dan ISA +30 secara berturut-turut yaitu $1946,48 \mathrm{~km}$ dan $2224,36 \mathrm{~km}$.

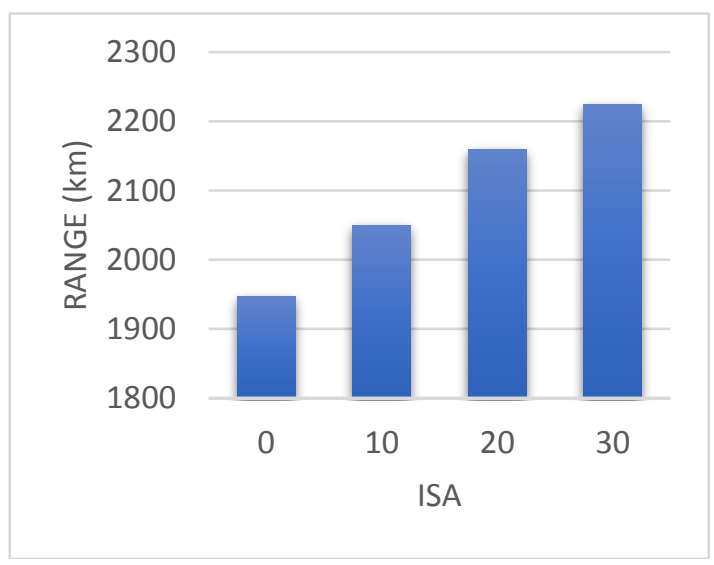

Gambar 4. Range Maksimum

\section{KESIMPULAN}

Penelitian mengenai pengaruh perubahan temperatur atmosfer terhadap range maksimum pesawat N219 pada fase terbang jelajah yang telah dilakukan dapat memberikan kesimpulan yaitu range maksimum pesawat dipengaruhi oleh berbagai aspek. Kondisi atmosfer berpengaruh terhadap massa jenis udara. Massa jenis udara semakin menurun seiring dengan bertambahnya peningkatan temperatur terhadap kondisi ISA 0. Selain dari faktor kondisi atmosfer, range maksimum pesawat juga dipengaruhi oleh aspek lain yaitu karakteristik pesawat tersebut. Specific fuel consumption yang diperoleh dari data hasil penerbangan perdana (flight test) pesawat N219 menunjukkan bahwa konsumsi bahan bakar pada pesawat semakin menurun seiring dengan bertambahnya kecepatan terbang serta semakin meningkat seiring dengan bertambahnya peningkatan temperatur terhadap kondisi ISA 0.
Kecepatan untuk range maksimum yang diperoleh menggunakan metode specific air range menunjukkan bahwa kecepatan terbang untuk memperoleh range maksimum semakin meingkat seiring dengan bertambahnya peningkatan temperatur terhadap kondisi ISA 0. Namun hal ini terjadi hingga batas ISA +20 , dan kecepatan kembali mengalami penurunan pada kondisi ISA +30 . Sama halnya dengan kecepatan, fuel flow juga mengalami penurunan seiring dengan peningkatan temperatur terhadap kondisi ISA 0 , dan kembali mengalami penurunan pada kondisi ISA +30 . Fuel flow memiliki hubungan berbanding lurus dengan kecepatan sehingga fuel flow meningkat seiring dengan meningkatnya kecepatan.

Waktu tempuh pesawat pada fase terbang jelajah di bawah kondisi ISA 0 hingga ISA +30 mengalami peningkatan. Range maksimum juga memiliki hubungan yang sama dengan temperatur seperti waktu tempuh pesawat. Range maksimum pesawat pada kondisi ISA 0 hingga ISA +30 terus mangalami peningkatan. Hal ini menunjukkan bahwa waktu tempuh pesawat dan range maksimum pesawat memiliki hubungan yang berbanding lurus dengan peningkatan temperatur terhadap kondisi ISA 0.

Peningkatan temperatur terhadap kondisi ISA 0 berpengaruh terhadap beberapa aspek yaitu penurunan massa jenis udara, peningkatan kecepatan maksimum yang disebabkan oleh peningkatan specific air range, dan bahan bakar yang lebih hemat akibat dari penurunan fuel flow. Sehingga range maksimum pesawat N219 semakin meningkat seiring dengan peningkatan temperatur terhadap kondisi ISA 0.

\section{SARAN}

Saran yang dapat disampaikan untuk penelitian selanjutnya yaitu perlu dilakukan validasi data karena pesawat N219 masih dalam masa uji coba terbang.

\section{DAFTAR PUSTAKA}

[1] Ojha, S, K., 1995. Flight Performance of Aircraft. Washington DC: American Insitute of Aeronautics and Astronautics, Inc.

[2] Turgut, E. T. et al., 2014. Fuel Flow Analysis for The Cruise Phase of Commercial Aircraft on Domestic Routes. Aerospace Science and Technology, Volume 37, pp. 1-9.

[3] Rivas, D., Garcia, O. L., Esteban, S. \& Gallo, E., 2010. An analysis of maximum range cruise including wind effects. Aerospace Science and Technology, Volume 14, pp. 38-48.

[4] Ruijgrok, G., 1990. Elements of Airplane Performance. Netherlands: Delf University Press. 
[5] Fadholi, A., 2013. Studi Pengaruh Suhu dan Tekanan Udara terhadap Daya Angkat Pesawat di Bandara S. Babullah Ternate. Teori dan Aplikasi Fisika, Volume 01, pp. 121-129.

[6] Filippone, A., 2008. Comprehensive analysis of transport aircraft flight performance. Progress in Aerospace Sciences, Volume 44, pp. 192-236.
[7] Baklacioglu, T., 2016. Modeling the fuel flow-rate of transport aircraft during flight phases using genetic algorithm-optimized neural networks. Aerospace Science and Technology, Volume 49, pp. 52-62. 